Nova Southeastern University

Florida

NSUWorks

NOVA SOUTHEASTERN

UNIVERSITY

Winter 1-1-2012

\title{
Revolutions and Expatriates: Social Networking, Ubiquitous Media and the Disintermediation of the State
}

Jon M. Garon

Follow this and additional works at: https://nsuworks.nova.edu/law_facarticles

\section{Recommended Citation}

Jon M. Garon, Revolutions and Expatriates: Social Networking, Ubiquitous Media and the Disintermediation of the State, 11 J. INT. BUS. L. 293 (2012).

This Article is brought to you for free and open access by the Shepard Broad College of Law at NSUWorks. It has been accepted for inclusion in Faculty Scholarship by an authorized administrator of NSUWorks. For more information, please contact nsuworks@nova.edu. 


\section{Journal of InTERnational Business \& Law}

A Publication of the Hofstra University School of Law and THE Frank G. ZaRB SCHOOL OF Business

\section{LEGAL \& BUSINESS ARTICLES}

The Counter-Productivity of ICSID

Denunciation and Proposals for Change ....... Diana Marie Wick 239

REVOLUTIONS AND EXPATRIATES:

Social Networking, Ubiquitous Media

and the Disintermediation of the State ........... Jon M. Garon 293

A Tale of Two Cities: Business Trust

Listings and CAPITAL Markets IN

SINGAPORE AND HONG KoNG....................... Norman P. Ho 311

Current Issues in Financial Regulation, and the Return of the Polttical Economy ........... John Nugee 333

Managerial Motivation and Determinants of their Performance: A Comparison of Middle-Level

Managers From the United States and Europe . Anil Mathur, Ph.D. 339

\section{NOTES \& STUDENT WORKS}

Regulating the Regulators: A Solution to

Foreign Corrupt Practices Act Woes ....... Cyavash Nasir Ahmadi 351

GOOD FOR THE BOTTOM LiNE: INCENTIVIZING

Private Companies to Join the

Global Network INITIATIVE

Arielle Joy Albert 379

National Marketing Gone Unintentionally Global:

DiRECT-TO-CONSUMER ADVERTISING OF

Pharmaceutical Products and the Internet ....... Jacqueline West 405 


\title{
REVOLUTIONS AND EXPATRIATES: SOCIAL NETWORKING, UBIQUITOUS MEDIA AND THE DISINTERMEDIATION OF THE STATE
}

\author{
Jon M. Garon*
}

\author{
If I forget you, O Jerusalem, \\ let my right hand forget its skill! \\ Let my tongue stick to the roof of my mouth, \\ if I do not remember you, \\ if I do not set Jerusalem \\ above my highest joy! ${ }^{1}$
}

You ask me about that country whose details now escape me,

I don't remember its geography, nothing of its history

And should I visit it in memory,

It would be as I would a past lover,

After years, for a night, no longer restless with passion, with no fear of regret.

I have reached that age when one visits the hear merely as a courtesy. ${ }^{2}$

\section{INTRODUCTION}

From the growth of Roman domination over Greece and Egypt or the binding of independent Chinese states into unified China through the Emperor Qin's adoption of a common written language and common currency, much of world history has turned on the tension between the populace in a region and its cultural brethren in the diaspora. The contrast between the words of the Psalm and the poetry of Faiz articulate the tension felt in expatriate communities and the divergent experiences of diaspora. ${ }^{3}$ Unlike any prior era in history, however, modern technology allows émigrés and refugees to participate in the cultural life of their homeland at unprecedented levels. These expatriates may form communities focusing on the land they have left, vote in elections in their homelands, and participate in the economic life of their former state. As a result, in politics, commerce, and community, the twentieth century

\footnotetext{
* Director, NKU Chase Law \& Informatics Institute and Professor of Law, Salmon P. Chase College of Law, Northern Kentucky University; J.D. Columbia University School of Law 1988.

1 Psalm 137:5-6 (English Standard).

2 Fatz AhMed Faiz, "Let me think," ll. 1-6, excerpt reprinted in Devesh Kapur, Diaspora, Development, and Democracy: The domestic Impact of International Migration from India 210 (2010).

3 In the case of the people of King David, the traditional author of Psalm 137, the Jews were exiled from Jerusalem when the city was captured by the Babylonian army in $587 \mathrm{BCE}$. Members of the community not killed during the invasion were exiled to Babylon. When Persia overthrew Babylon in $533 \mathrm{BCE}$, the Jewish community was allowed to return to their homeland. See Brief History of Israel and the Jewish People, ISRAEL SCIENCE AND TeChNOLOGY, http://www.science.co.il/Israel-history.php (last visited Jan, 22, 2012).
} 
role of the state has been challenged by new technologies that reduce barriers among states and improve communications among communities.

Nowhere has this transformation been greater than in the Middle East, a region shaped by arbitrary political expediency and under tremendous popular pressure to redefine itself. But these transformations are not merely the populist uprisings of Tunisia, Egypt, Libya and Syria; they can be seen in economic transformations of Asia and economic harmonization between Europe and North America.

In all political, economic, and social spheres, the role of social media and non-mediated communication has systematically reduced the role of the state and empowered a new network dynamic that will define the coming decades of the twenty-first century.

A survey of Diaspora literature, however, suggests that while social media and Internet-age communications tools expand the role of Diaspora communities, they are merely a tool. Some expatriate communities are engaged in peace building efforts and economic development while others are more intractable and using these tools to fund or promote armed conflict. These communities themselves are heterogeneous, so any generalization oversimplifies the community and its internal conflicts. The real lesson, then, is that the relative power of the state and the expatriate community are shifting away from the state-sometime evoking additional conflicts. Whatever the role, the significance of the Diaspora will increase and play a more significant part on their former homeland. The role will be determined by the conditions and the community.

This Article first reviews the current role of social media in ongoing political transformations. The second section compares these uprisings to the economic phenomena of disintermediation and unbundling of historical economic relationships between content distribution and its costs. It explains this media transformation in terms of traditional media, user generated content, and the ephemeral communications of social media. The final section then suggests how the changing influence of the networked cultural community and the state will reshape Diaspora politics in the twenty-first century. It makes some predictions regarding the declining role of the state and the rise of the cultural community-a phenomenon which suggests a reemergence of clan culture in parts of the Middle East and political tension at arbitrary political borders.

\section{SOCIAL MEDIA'S ROLE IN RECENT POLITICAL TRANSFORMATIONS}

The world is changing in profound and perhaps unpredictable ways. After decades of hated dictatorial rule, the flame that sparked a revolution was the self-immolation of protester Mohamed Bouazizi and the social media which reported his martyrdom. ${ }^{4}$ Instead of the newspapers, radio or television, the story of the martyrdom was carried through social media. ${ }^{5}$

"The fact that it became public, and became the catalyst for anger which led to the overthrow of Zine el-Abidine Ben Ali was thanks to Facebook, Twitter and blogs outside the regime's control."6 A staff member for Tunisian newspapers LaPresse and Essahafa commented " $[w]$ had let down our readers for many years, we had failed in our duty as journal-

\footnotetext{
${ }^{4}$ Kim Sengupta, Tunisia media throw off censor's shackles after decades of fear and collaboration, THE INDEPENDENT, Jan. 20, 2011, at 24, available at http://www.independent.co.uk/news/world/africa/tunisianmedia-throw-off-censors-shackles-after-decades-of-fear-and-collaboration-2189241.

5 See id.

6 Id.
} 


\section{REVOLUTIONS AND EXPATRIATES}

ists. How many important stories have been buried? How much truth has been replaced by lies?"7 Instead of the traditional media assisting, it was ineffective-if not complicit-in maintaining the status quo.

The fall of Tunisia's dictatorship was not solely the social media power of Facebook and Twitter. Nor was the protest of Mr. Bouazizi likely more than a catalyst. Decades of labor unrest had stressed the nation and erupted often in the years leading up to the overthrow. ${ }^{8}$ Many converging forces were at play, including the information gleaned from the cache of United States diplomatic cables released by a disgruntled military employee to WikiLeaks. ${ }^{9}$ The WikiLeak cables embarrassed U.S. and world leaders and potentially undermined the candidness of diplomatic efforts, ${ }^{10}$ but they have already had some direct impact on the populations of the world held in the dark through totalitarian control of the media.

In Tunisia, the WikiLeaks disclosures fueled the outrage spawned by Mr. Bouazizi. "Further ammunition came from hunting through U.S. diplomatic cables made public by WikiLeaks charting the venality of the President, his wife, Leila Trabelsi, and the kleptocracy they headed." 11

The impact of the revolution in Tunisia has been shared and tweeted across the region. ${ }^{12}$ "In Egypt, the tried-and-true tool for opponents of President Hosni Mubarak in recent years has been Facebook. Most recently, it was on Facebook . . . which boasts five million users in Egypt, the most in the Arab world-where youthful outrage over the killing of a prominent activist spread, leading to the protests in Cairo's Tahrir Square . . .."13 Equally important, the cell phone camera has brought the bloody images of protest to the public $^{14}$ _echoing the impact network television news once had on the U.S. perception of the war in Vietnam. ${ }^{15}$

7 Id.

8 See Tunisian Labor Leaders call for support of Libyan Revolution, SACRAmento Progressive AlLIANCE (Mar. 21, 2011), http://sacramentopa.blogspot.com/201 1/03/tunisian-labor-leaders-call-for-support.html.

${ }^{9}$ Scott Shane \& Andrew W. Lehren, Leaked Cables Offer Raw Look at U.S. Diplomacy, N.Y. Times (Nov. 28, 2010), http://www.nytimes.com/2010/11/29/world/29cables.html?pagewanted=all ("[A] quarter-million confidential cables ... provides an unprecedented look at back-room bargaining by embassies around the world, brutally candid views of foreign leaders and frank assessments of nuclear and terrorist threats."); Joby Warrick, Cables leak reveals flaws of information-sharing tool, WASH. POsT, Dec. 31, 2010, at A01 ("U.S. investigators suspect that Bradley Manning, an Army private stationed in the Persian Gulf, downloaded the 250,000 State Department cables to compact discs from a computer terminal in Kuwait. He then allegedly provided the files to WikiLeaks, which shared them with newspapers and posted hundreds of them online.").

10 Shane \& Lehren, supra note 9 ("The White House said the release of what it called 'stolen cables' to several publications was a 'reckless and dangerous action' and warned that some cables, if released in full, could disrupt American operations abroad and put the work and even lives of confidential sources of American diplomats at risk.").

II Sengupta, supra note 4, at 24.

12 See Jennifer Preston, While Facebook Plays a Star Role in the Revolts, Its Executives Stay Offstage, N.Y. Trmes, Feb. 15, 2011, at A10.

13 See Cecilia Kang \& Ian Shapira, Facebook's Egypt Conundrum, WASH. Post, Feb. 3, 2011, at A13.

14 See Jennifer Preston \& Brian Stelter, Cellphones Become the World's Eyes and Ears on Protests, N.Y. Times, Feb. 19, 2011 , at A11 ("A novelty less than a decade ago, the cellphone camera has become a vital tool to document the government response to the unrest that has spread through the Middle East and North Africa.").

15 See Morena Groll, Vietnam War Coverage on U.S. Television Newscasts 11 (2007); see also Michael Bibby, The Vietnam war and Postmodernity 220-21 (2000). 
As of the time of this writing, Egypt's President Hosni Mubarak has resigned and been placed on trial, ${ }^{16}$ Libya's bloody civil war resulted in the overthrow of the Gadaffi regime, ${ }^{17}$ protests have been held in Bahrain and Yemen, and ameliorative efforts haven taken place in Saudi Arabia and Jordan. In China, the phrase "Jasmine Revolution" has been blocked from the Internet. ${ }^{18}$ Most explosively, Syria is devolving into an armed struggle of civil conflict and possible chaos. ${ }^{19}$

As the professional media becomes supplemented or supplanted by blogs, video and photo sites, personal websites, whistle-blower websites and social media, the movement and impact of communications will inevitably change. As was the case in Tunisia, governments may lose some of the formal or informal controls they have over the dissemination of news and geographic borders will no longer be barriers to dissemination of content. Other governments will try to tighten control. ${ }^{20}$ The predictions that Iran's government would fall to the power of the twitter-enabled crowd proved naïve. ${ }^{21}$ Still, the cumulative effect remains startling.

The phenomenon has been described in the Middle East as "a system in a state of self-organized criticality. A self-organized critical system is defined as a complex system which-without explicit design or deliberate external shaping-trends towards a critical state. This critical state is unstable and subject to cascades of varying sizes into less organized states." 22 Throughout the region, the issues of poverty, unemployment and dictatorship have festered. "Tensions in the region have built up to a critical state, and the uprising in Tunisia acted as the grain which began the cascade." 23 Whether the organized criticality is limited to a country, to a region like the Middle East, or to the globe remains uncertain.

${ }^{16}$ See Anthony Shadid And Heba Afify, Egypt's Military Leader Testifies at Mubarak Trial, N.Y. TimEs, Sept 25, 2011 at A10.

17 See Kayla Webley, Top 15 Toppled Dictators, TIME (Oct. 20, 2011), http://www.time.com/time/specials/ packages/article/0,28804,2097426_2097427_2097445,00.html.

18 Ian Johnson, Calls for a 'Jasmine Revolution' in China Persist, N.Y. TIMEs, Feb. 24, 2011, at A14.

19 See Kareem Fahim \& Steven Erlanger, Syria Chaos Claims Priest and an Aid Group Official, N.Y. TIMES, Jan. 26, 2012, at A10.

${ }^{20}$ See Michael Wines, Crackdown Continues on Activists in China, N.Y. TıMEs, Jan. 18, 2012, at A8; Nicholas Kristof, Banned in Beijing!, N.Y. TIMEs, Jan. 23, 2011, at WK10.

21 See Evgeny Morozov, The Net Delusion 4-5 (2011).

22 Karla Z. Bertrand \& Yaneer Bar-Yam, Contagion and cascades through the Middle East: Tunisia, Egypt, Jordan, Syria . . . New England Complex Systems Institute, Feb. 1, 2011, available at http://www.necsi.edu/ research/social/middleeastcontagion.html.

The archetypal example is a sandpile slowly growing by additional sand dropped onto the pile, grain by grain. A single grain dropped on the pile can occasionally cause an "avalanche" of unpredictable size. The initial grain can cause other grains to fall, which in turn can effect still more. The avalanches display power-law behavior: small ones happen much, much more frequently than large ones.

The basis for the cascade is an underlying buildup of tensions (like the sand) which has to reach a point of crisis at any one location before actions are taken. However, this point of crisis also depends on the actions of neighbors. Thus, once something happens in one place, the outbreak cascades. The current unrest can thus be considered as an avalanche in the sandpile of the Middle East.

Id.

${ }^{23}$ Id. 
At its extreme, this interconnectedness may illustrate the declining role of the nationstate in an information economy. ${ }^{24}$ As both goods and information have moved toward a networked, global economy, the ability of a country to control production of goods and management of content has ebbed. ${ }^{25}$ The means of production are distributed throughout multiple jurisdictions and the economic influence of any one government is diminished because of the enterprise's diffusion. Moreover, the global trade has increasingly become information and intangible goods, with "at least 70\%" of the world's gross domestic product being wholly or partially intangible goods. ${ }^{26}$

The information globalization has transformed the relation of the enterprise and the state. ${ }^{27}$ And the transformation is stark:

For the first time in history, the basic unit of economic organization is not a subject, be it individual (such as the entrepreneur, or the entrepreneurial family) or the collective (such as the capitalist class, the corporation, the state) ... . [T]he unit is the network, made up of a variety of subjects and organizations, relentlessly modified as networks adapt to supportive environments and market structures. ${ }^{28}$

The new network of economic organization has made its impact felt most profoundly in the Tunisian revolution, but shows its influence everywhere. Journalist Thomas Friedman has written extensively on the phenomenon:

[T]here have been three great eras of globalization. The first lasted from $1492 \ldots$ until around 1800 . I would call this era Globalization $1.0 \ldots$ [T] he key agent of change, the dynamic force driving the process of global integration was how much brawn-how much muscle, how much horsepower, wind power, or, later, steam power-your country had and how creatively you could deploy it .... The second great era, Globalization 2.0 , lasted roughly from 1800 to 2000 , interrupted by the Great Depression and World Wars I and II ... [The driving force] was multinational companies .... It was during this era that we really saw the birth and maturation of a global economy, in the sense there was enough movement of goods and information from continent to continent for there to be a global market, with global arbitrage in products and labor .... [I]n Globalization 3.0-

\footnotetext{
24 See generally Manuel Castells, The Rise of the Network Society: The Information Age: Economy, Society, and Culture Volume I 167 (2d ed. 2009) (Hereinafter Castellis, Network Society).

25 Manuel Castells, Information Technology, Globalization and Social Development, U.N. Res. Inst. Soc. Dev., Discussion Paper No. 114, at 4 (Sept. 1999) (hereinafter Castells, Information Technology) ("In the early 1990 s multinational corporations employed directly 'only' about 70 million workers, but these workers produced one third of the world's total private output, and the global value of their sales in 1992 was US $\$ 5,500$ billion, which is 25 percent more than the total value of world trade in that year.").

${ }^{26}$ Luciano Floridi, Philosophy of Technology: Critical Reflections, 23 KNOwledge, TeCH. \& Pol'Y (forthcoming 2012), available at http://www.philosophyofinformation.net/publications/pdf/tpoiaacf.pdf.

27 Culture and Globalization, GLoBalization101.ORG, 2 (2011), http://www.globalization 101.org/uploads/ File/Culture/cultall2011.pdf (defining globalization as "acceleration and intensification of economic interaction among the people, companies, and governments of different nations."). See generally Peer Zumbansen, Values: Law after the Welfare State: Formalism, Functionalism, and the Ironic Turn of Reflexive Law, 56 Ам. J. CомР. L. 769 (2008).

28 Castells, Network Society supra note 24 , at 214.
} 
the force that gives it its unique character-is the newfound power for individuals to collaborate and compete globally. ${ }^{29}$

The transformation of Friedman's Globalization 3.0 is that both the state and the multinational company are losing control of the means of global production. ${ }^{30}$ The tools of the networked globalism have moved from the state to the multinational company and now to the individual. ${ }^{31}$ Globalization was not the goal for these innovations but rather the consequence. "[G]lobalization is a new historical reality . . . inscribed in processes of capitalist restructuring, innovation, and competition, and enacted through the powerful medium of new information and communication technologies." 32

"The culture war ... [is] about what level of autonomy we allow individuals to express themselves." This is true for the individual, among each community, in every state, and in cultures than exist beyond the state-whether in the social affinity of one's ancient homeland or in the diaspora of expatriate indigenous cultures. ${ }^{33}$ "The rise in extra-territorial relations, including the expansion of transnational and international administrative and judicial entities, further challenges the notion of absolute territorial borders." 34 "Observers of globalization are increasingly recognizing that globalization is having a significant impact on matters such as local cultures, matters which are less tangible and hard to quantify, but often fraught with intense emotion and controversy." 35 The state is diminishing in importance as its citizens are rising.

The softening of the nation-state's territorial borders has not only the deconstructive aspects, but also constructive attributes. Expatriate and Diaspora communities often participate in the cultural and economic life of their former lands.

As a whole, Diaspora groups frequently play a critical role in accelerating technology exchange and foreign direct investment in their home economies. For some, there is non-financial intrinsic motivation. In addition to utilizing [Information and Communication Technologies] to enhance remittance services, Diasporas are helping to bridge the digital divide in their countries of origin by incorporating technology transfer into social, economic, and political assistance activities. ${ }^{36}$

The question is not whether new communications technologies are transforming the relationship of citizens with their former countrymen, but how these technologies are shaping

\footnotetext{
29 Thomas Friedman, The World is Flat 9-10 (2005).

30 See Dan Hunter, Culture War, 83 Tex. L. REv. 1105, 1107 (2005).

31 See id. at 1135-36.

32 Castells, Information Technology, supra note 25 , at 5.

33 See Austen L. Parrish, Lands, Liberties, And Legacies: Indigenous Peoples and International Law: Theoretical Approaches to International Indigenous Rights: Changing Territoriality, Fading Sovereignty, and the Development of Indigenous Rights, 31 AM. INDIAN L. REv. 291, 302 (2007) ("the salience of the sovereign state, strictly defined by its territorial borders, has slowly declined.").

34 Angela R. Riley, Good (Native) Governance, 107 CoLum. L. Rev. 1049, 1058 (2007).

35 Globalization 101.org, supra note 27 at 2.

36 Joseph Guerson \& Anne Marie Spevacek, U.S.A.I.D., Diaspora-Development Nexus: The Role Of ITC 7 (2008).
} 
commerce, culture; and conflict. Put another way, in the flattened world of the information age, how is it that all politics remain local ${ }^{37}$

Left unanswered from the uprisings in Egypt, Tunisia, Libya, and elsewhere is the nature of the country left in its wake. Are these uprisings "democratic," and if so, what does this mean? The American revolution contemplated this challenge:

Justice is the end of government. It is the end of civil society. It ever has been and ever will be pursued until it be obtained, or until liberty be lost in the pursuit. In a society under the forms of which the stronger faction can readily unite and oppress the weaker, anarchy may as truly be said to reign as in a state of nature, where the weaker individual is not secured against the violence of the stronger; and as, in the latter state, even the stronger individuals are prompted, by the uncertainty of their condition, to submit to a government which may protect the weak as well as themselves; so, in the former state, will the more powerful factions or parties be gradually induced, by a like motive, to wish for a government which will protect all parties, the weaker as well as the more powerful. ${ }^{38}$

The goal, to Madison, was not to create a hegemonic power that eliminated discord and dissent, but a factional government focused on justice and civil liberty. In this view, the federalist nature of co-equal branches of government and tension between federal and state governments served a moderating purpose to disaggregate power and thus limit the temptation for its abuse. ${ }^{39}$ These concepts, flowing from John Milton and John Locke, focus on liberalism or "the right of every individual to self-determination at the centre of justice." 40 In contrast, a more social philosophy suggested by Rousseau provides that the state has a duty to promote equality. ${ }^{41}$

The structural nature of the twentieth century has been at odds with Madison's view of justice. "The history of the first three quarters of the twentieth century can be seen as one where states held clear authority within their borders, and governments acquired growing functions which they tended to perform on their own." 42 Whether nation-states adhered to the goals of Rousseau, they certainly obtained the power to play such a role. The power of na-

\footnotetext{
37 See Eric X. Li, Globalization 2.0: China's Parellel Internet, Huffington Post (Jan. 20, 2012), http:// www.huffingtonpost.com/eric-x-li/china-internet_b_1217436.html ("The easy scalability of the Internet makes it perhaps the most powerful phylogenetic invasion of the body politic in recent times.”).

38 The Federalist No. 51, at 266 (James Madison) (Ian Shapiro ed. 2009).

${ }^{39} \mathrm{Id}$. at 265 ("It is of great importance in a republic not only to guard the society against the oppression of its rulers, but to guard one part of the society against the injustice of the other part.").

40 Thomas Fleiner \& Lidija R. Basta Fleiner, Constitutional Democracy in a Multicultural and Globalized WorLd 157 (2009).

${ }^{41}$ Id. It is therefore one of the most important functions of government to prevent extreme inequality of fortunes; not by taking wealth from its possessors, but by depriving all men of means to accumulate it; not by building hospitals for the poor, but by securing the citizens from becoming poor . . . . Id. (quoting J.J. Rousseau, A Discourse on Polttical Economy (1755)).

42 Richard Batley \& George A. Larbi, The Changing Role of Government: The Reform of Public Services in Developing Countries 2 (2004).
} 
tions grew and treaties among nations tended to reinforce the sovereignty of individual states. ${ }^{43}$

As communications technologies improved, global travel increased and the transaction costs of trade declined. In the late twentieth century, however, a new paradigm began to emerge.

The latter part of the twentieth century and the early twenty-first century have seen the emergence of a more porous view of the nation state, and changed views of the role of government: it would perform fewer functions on its own and more in partnership with other actors. Associated with this change in public policy about what the state was to do was a consequential change in how it was to act. ${ }^{44}$

"Liberty, equality, internal peace and the universal common good were all undisputed goals of the state. But what was in dispute was the relative priority that should be accorded to these goals, and real content or meaning of each of them." 45 Whether by cause or consequence, the impact of these changing relationships has adjusted the ability of citizens to act outside the control of their state-without the state as an intermediary. ${ }^{46}$

The rise in significance of communities within states and communities sharing common identity divided among political states creates further tension on the philosophical role of the state. A political concept of communitarianism "refers to the values of the communities and prioritises the value of common welfare over the value of individual liberty and individualistic capitalism." 47 By emphasizing the rights of the group's common welfare over the interests of the individual, the values of communitarianism can be seen to dovetail with interests in expatriate and Diaspora communities to the extent communitarianism extends to protections of minority communities' interests from majoritiarian pressures. ${ }^{48}$

At the same time, the rights of individuals to assert their interests within their community has the potential to create unequal treatment among various individuals under the law. Article 4 of the Framework Convention for the Protection of Minorities ${ }^{49}$ articulates this very tension:

Article 4.2. The Parties undertake to adopt, where necessary, adequate measures in order to promote, in all areas of economic, social, political and cultural life, full and effective equality between persons belonging to a na-

\footnotetext{
43 See Joseph S. Nye Jr., Information Technology and Democratic Governance, in GovernANCE.COM Democracy in the Information Age 3-5 (Elaine Ciulla Kamarck \& Joseph S. Nye, Jr., eds., 2002).

44 BAtley \& LARBI, supra note 42 , at 2.

45 Fleiner \& Fleiner, supra note 40 , at 158.

46 See BATLEY \& LARBI, supra note 42 , at 2.

47 FLEINER \& FLeINER, supra note 40, at 161 (emphasis added) ("Liberties are interpreted from the point of view of the community. Harmony of the community and not individual liberty becomes the main goal of the state. The controversy over 'Asian values' relative to human rights has also to be seen within this context."). 48 See generally, Framework Convention for the Protection of Minorities, Council of Europe, 3 (Feb. 1, 1995), http://www.coe.int/t/dghl/monitoring/minorities/1_atglance/PDF_H(1995)010_FCNM_ExplanReport_ en.pdf ("Article 1. The protection of national minorities and of the rights and freedoms of persons belonging to those minorities forms an integral part of the international protection of human rights, and as such falls within the scope of international co-operation.").

49 See id. at 3-4.
} 


\section{REVOLUTIONS AND EXPATRIATES}

tional minority and those belonging to the majority. In this respect, they shall take due account of the specific conditions of the persons belonging to national minorities.

Article 4.3. The measures adopted in accordance with paragraph 2 shall not be considered to be an act of discrimination. ${ }^{50}$

The Framework Convention for the Protection of Minorities neatly places the liberalism ideal of protection of the individual and the socialistic ideal of a society engendering equality with the minority-communitarian structure of minorities protected from the majority-and presumably each other-while advancing a socialist ideal within the state. This is the correct result since, were the philosophy liberalism, the protection of the minority would be secondary to that of the individual. While not consistent with Locke and Milton, such a result may be more in line with Madison and the goal of competing factions to assure no dominance of any majority and a lessening of governance itself.

In contrast with the traditional notion of the state, organized communities can increasingly maintain the cohesive culture or substantive beliefs of their peoplehood while living in a geographically distinct area. Admittedly, "it is difficult to offer an unproblematic shared understanding of the concept of diaspora but . . . there is enough commonality of understanding of the concept that a comparative investigation ... makes sense." 51 Examples include communities for whom the historical boundaries of clan, language, and culture were sundered by political forces. Other examples include refugees living just over the border from their homes, awaiting political stability or the end to living conditions that preclude a return home. Whether they have fled oppression or draught, the refugees remain citizens of their country with no integration with the region providing temporary shelter.

Still other examples include émigrés who have left their original homeland for another country. Whether for economic opportunity or to avoid the conditions of their homeland, these individuals have embarked upon a series of difficult steps to establish themselves in a new country. Modern émigrés, however, may find themselves connected through the ubiquity of traditional media and the convenience of social media to be communicating with the country they have left as often as with people in the country to which they now belong.

In each of these examples, and the many additional variations, the expatriates and members of the diasporic community inevitably play an important role in political and economic development.

The capacity of some diasporas to secure tangible and intangible resources in support of armed conflicts, the often opaque institutional and network structures that can allow for transnational transfers of arms and money to state and non-state actors, including terrorist groups, as well as to more deserving causes (for instance as humanitarian assistance), along with rapid transnational communication, mean that, in the era of globalization, diaspo-

so Id.

51 Hazel Smith, Diasporas in international conflict, in Diasporas in conflict: Peace-makers or PeaceWRECKERS? 3-4 (Hazel Smith \& Paul Stares eds., 2007), availible at http://i.unu.edu/media/publication/000/002/ 187/1140-diasporasinconflict.pdf. 
ras have been reconstructed as new and potentially powerful actors in international politics. ${ }^{52}$

Within a country's minority community or the expatriate community outside that country, the influence wielded may be used to further the group's political aspirations through peaceful means or through military and paramilitary action. Studies of Diaspora communities suggest that some are destabilizing while others are effective at nation-building. ${ }^{53}$ The broad array of empirical evidence and scholarly research has failed to predict any pattern regarding how any particular expatriate community will influence a particular conflict.

\section{DISINTERMEDIATION OF THE STATE}

What can now be predicted, however, is that the changing role of the nation-state has created an opportunity for expatriate and diasporic communities to be more influential on the outcome of the political conflicts than they had been in the previous century. "Marshall McLuhan once prophesied that communications technologies would turn the world into a global village. Instead of a single cosmopolitan community, however, they may have produced a congeries of global villages, each with all the parochial prejudices that the word implies, but with a greater awareness of global inequality . . . all in the presence of television cameras and the Internet." 54

As the state loses its grip on media regulation, economic policy, trade rules, conflict resolution, and access to information, members of the community living outside the jurisdiction have fewer barriers to participate than ever before and lower costs for communicating, financing. and traveling than at any time in history.

Whatever the political philosophy, the changing role of the state in its relationship with its citizenry fits the classic economic paradigm of disintermediation. If a nation can be analogized to a business, ${ }^{55}$ its disintermediation occurs "where changes in the current business model or advances in technology mean that a company ceases to need to use intermediaries to create the value sought by end customers." 56 Although disintermediation is more typically applied in the economic or transactional context, it applies with equal force to the relation between the individual and the state. State monopolies in journalism, telecommunications, education, finance and production have all declined. 57 "The importance of assess-

\section{Id. at 3. \\ 53 See id.}

54 Timothy L. Thomas, The Russian View of Information War, Foreign Military Studies Office (Feb. 7-9, 2000), http://fmso.leavenworth.army.mil/documents/Russianvuiw.htm (quoting Joseph Nye, Redefining the National Interest, 78 ForeiGn AfFAIRs 22, 26 (1999)).

55 This is a point of considerable political debate, beyond the scope of this article.

56 Martin Christopher, Adrian Payne \& David Ballantyne, Relationship marketing: creating shareholder value 173 (2002). See also Peter Lawrence, The Change Game: How Today's Global Trends Are Shaping Tomorrow's Companies 142 (2004) ("In a strict sense disintermediation occurs when some organization is cut out of the loop, as when airlines exhort and/or pressurize people to book via telephone call centres or on the Internet ....").

57 See generally Vincent Della Sala, Governance of Politics without a Centre, in WHO IS AFRAID OF THE State?: Canada in a World of Multiple Centres of Power 137-40 (Gordon Smith \& Daniel Wolfish eds., 2001) ("The sources for this decline are found not simply among the velocity and mobility for capital but in a number of social and economic factors that have disrupted the symmetry of the state's authority with territorial boundaries and weakened individuals' sense of identity with political communities."). 
ments of bond-rating agencies such as Standard \& Poor's and Moody's for debates about budgetary politics is an indication that social forces beyond national borders are curtailing the boundaries for state action." 58 Similarly, "authority for many areas of the public realm, such as agriculture and monetary policy, is increasingly in the hands of the structures that rival the state." 59

This same trend has moved the locus of power outside of government, towards lower governmental subdivisions ${ }^{60}$ and to supranational organizations such as the European Union. ${ }^{61}$

The cause of disintermediation is not merely the public's gravitation towards greater efficiency, but perhaps also the challenge of scalability of the current governance structure, or as Daniel Bell described it, the state has "become too small for the big problems of life and too big for the small problems." 62 Bell states that "the older social structures are cracking because political scales of sovereignty and authority do not match the economic scale. In many areas we have more and more economic integration and political fragmentation ...."63

Moreover, the diminution of the state flows as a natural consequence from the emergence of unmediated services made available to its citizens. There may be a wide array of causes for any particular government to provide fewer direct services, including a libertarian political philosophy, increased costs, decreased resources, or lessened demand by the public. International commercial disputes-and domestic contract disputes-are increasingly resolved through privatized arbitration instead of sovereign judiciaries; ${ }^{64}$ increased privatization of direct services; social services are returning to the provenance of the nonprofit sector; and governmental owned or licensed broadcasters are being supplemented or supplanted by social media.

In these and many other examples, government has undergone its own disintermediation. In addition, automation has further reduced the interaction between the public employee and the public. For example, governmental agencies have used the efficiencies of Internet-based information, fill-in forms and similar tools to reduce the number of employees-gaining efficiency but losing the interactions between the government official and member of the public. ${ }^{65}$ Once a service is provided through a website, does the citizen being served notice or care what entity is hosting the site?

The disintermediation of certain state functions would have little bearing on the broader public policy unless the services provided by the state are critical to a state's social

$58 I d$. at 138 .

59 Id.

60 Id. at 137 ("[E]ven the highly centralized European states such as France and Italy created sub-national levels of government in the $1970 \mathrm{~s}$ and $1980 \mathrm{~s}$. . . . Governments throughout the Organization for Economic Cooperation and Development (OECD) 'downloaded' a number of responsibilities to 'lower' levels throughout the 1990s.").

61 Id. at 138 ("More important, the recent evolution of the European Union has been a response to the recognition that the territorially defined limits of the state were inadequate in an interdependent global economy.").

62 Joseph S. Nye Jr., Redefining the National Interest, 78 Foreign AfF. 22, 26 (1999) (quoting Daniel BeLl, The Coming of Post Industrial Society: A Venture in Social Forecasting 94 (1998)).

${ }^{63}$ Nye, supra note 43 , at 3 (quoting BELL, supra note 62, at 94).

64 See Julius Melnitzer, International arbitration gets easier, Financial Post, Jan. 18, 2012, available at http:/ /business.financialpost.com/2012/01/18/international-arbitration-gets-easier/.

65 See G. David Garson, Public information technology: POlicy and Management issues 179 (2003). 
legitimacy. Can a government hold sway over its people if it is not the source of both legitimate authority and central services? Why does the U.S. military (as well as al-Qaeda and Hezbollah) emphasize the building of hospitals and schools within regions under their control, if not to assert de facto sovereignty through provision of central services? ${ }^{66}$

\section{NORMATIVE PERSUASION THROUGH SOCIAL TRENDS}

In 1990, John Ikenberry and Charles A. Kupchan postulated a refinement in theory of hegemonic power focused on the normative persuasion of primary states over their neighbors. ${ }^{67}$ They recognized that the power of a state-particularly a hegemonic state-comes in part from its control over "material incentives" affected through "threats of punishment or promises of reward." 68 But they also found that a hegemonic power exercises influence by "altering the substantive beliefs of leaders of other nations." 69 "Power is thus exercised through a process of socialization in which the norms and value orientation of leaders in secondary states change and more closely reflect those of the dominant state." By using soft influence--education, elite access, recognition and accolades, and similar techniques, the influencing nation shapes the values and culture of the other countries within its sphere of influence. $^{70}$

The soft influence can be seen when the children of foreign governments are educated at Harvard or in other elite U.S. universities; when state department dinners are treated as rewards for policy decisions; how trade missions are structured and staffed; which infrastructure projects are financed; and where culture and art exchanges are emphasized. Economic trade is both a tool for soft influence and a reward for it. ${ }^{71}$

Such techniques are used by every government to build alliances with its neighbors. Countries with greater resources are more influential.

The purpose of public diplomacy and strategic communication activities ... includes a renewed commitment to international exchange of persons that helps to serve the needs of the U.S. government in the following four areas:

\footnotetext{
${ }^{66}$ See, e.g., David Wood, Building Schools in Afghanistan: Not as Simple as ABC, Polrmics Dally (Aug. 13, 2009), http://www.politicsdaily.com/2009/08/13/building-schools-in-afghanistan-not-as-simple-as-a-b-c/; David Lewis, Lebanon - Party of God, FrontLine WorLd (May, 2003), http://www.pbs.org/frontlineworld/stories/ lebanon/thestory.html.

67 See John Ikenberry \& Charles A. Kupchan, Socialization and Hegemonic Power, 44 INT'L. ORG. 283, 290 (1990).

68 Id. at 285 .

69 Id.

70 See id.

71 This role of international trade may help explain the emphasis on TRIPS treaty agreements even for countries that have little or no ability to enforce or adjudicate such rights. See Peter Yu, TRIPS Enforcement and Developing Countries, 26 AM. U. INT'L L.REv. 727, 751 (2011) ("stronger [IPR] enforcement often comes with a hefty price tag and difficult trade-offs"). See generally Peter K. Yu, Enforcement, Economics and Estimates, 2 WIPO J. 1 (2010), availible at http://www.wipo.int/about-wipo/en/wipo_journal/pdf/wipo_journal_2_1.pdf (discussing relative costs of enforcement for the TRIPS Agreement).
} 
- underscore our commitment to freedom, human rights, and the dignity and equality of every human being;

- reach out to those who share our ideals;

- support those who struggle for freedom and democracy; and

- counter those who espouse ideologies of hate and oppression. ... With our partners, we seek to isolate and marginalize violent extremists who threaten the freedom and peace sought by civilized people of every nation, culture and faith. To that end, exchanges are designed to identify individuals who can impact wider segments of society, including exchangees who can document their activities through old and new media technologies, such as Web chats, documentaries, YouTube, and news media programs.

... A greater emphasis is placed on coordination of messages, proactive media bookings in regional media hubs (Dubai, Brussels, and London), and monitoring of global public opinion. Exchanges are viewed in the context of an ideological struggle and national security priority:

The U.S. is engaged in an international struggle of ideas and ideologies, which requires a more extensive, sophisticated use of communications and public diplomacy programs to gain support for U.S. policies abroad. To effectively wage this struggle, public diplomacy must be treated-along with defense, homeland security and intelligence-as a national security priority in terms of resources. We must continue to significantly increase funding for all public diplomacy and strategic communication programs, but specifically, we need urgent funding for priority programs such as people-to-people exchanges. ${ }^{72}$

As suggested by this governmental policy, United States policy understands exactly which forms of normative persuasion can be used to influence other constituencies. The U.S. State Department is reportedly seeking additional funds to do more. According to reports of Senate testimony, Secretary of State Hillary Clinton testified that "[d]uring the Cold War we did a great job in getting America's message out. After the Berlin Wall fell we said, 'Okay, fine, enough of that, we are done,' and unfortunately we are paying a big price for it," she said. 'Our private media cannot fill that gap." 73

Secretary of State Clinton focused on the state-sponsored media as competitors in the normative persuasion competition. " 'We are in an information war and we are losing that war. Al Jazeera is winning, the Chinese have opened a global multi-language television network, the Russians have opened up an English-language network. I've seen it in a few countries, and it is quite instructive,' she stated."74 Undoubtedly these media outlets have an impact, but only to the extent they are considered persuasive sources. Al Jazeera, unlike the

\footnotetext{
72 Nancy Snow, Public Diplomacy in a Changing World: Section Three: National Case Studies of Public Diplomacy and Commentary: International Exchanges and the U.S. Image, 616 ANNALS AM. ACAD. Pol. \& Soc. SCI. 198, 219-20 (2008)(quoting the June, 2007, report of the United States Strategic Communication and Public Diplomacy Policy Coordinating Committee)(internal quotations omitted).

73 Hillary Clinton Declares International Information War, RT.com (Mar. 4, 2011), http://rt.com/news/ information-war-media-us/.

${ }^{74} \mathrm{ld}$.
} 
other examples, is not a state-controlled news outlet and has some credibility as independent, particularly for issues within the Arabic and Islamic communities.

The rise of al Jazeera was not part of the moral persuasion theory developed by Ikenberry and Kupchan. Their approach emphasizes the role of the hegemonic state providing top-down persuasion, and fails to take into account the dynamic of organized factions, the power of self-identified communities, and the recent communications paradigm of many-tomany social media communications and citizen journalism. Nor does it take into consideration the influence of media on culture. ${ }^{75}$

In 1967, Marshall McLuhan predicted the change: “A new form of 'politics' is emerging and in ways we haven't yet noticed. The living room has become a voting booth. Participation via television in Freedom Marches, war, revolution, pollution, and other events is changing everything." understanding of social and cultural change is impossible without a knowledge of the way media work as environments." 77 As predicted, media, culture and politics have intertwined, with the relentless 24-hour news-cycle and social media serving as engine for the public's education, participation and media production. ${ }^{78}$

The description of U.S. public diplomacy, quoted above, incorporates the new social media tools as part of the tool set for people-to-people or cultural diplomacy. ${ }^{79}$ But the cultural diplomacy does not flow exclusively-or even primarily-through U.S. diplomatic channels or the channels of any governmental agency.

A common trope under this theme is the exporting of "American Values" from Hollywood, ${ }^{80}$ which has long been a regular point of international tension. ${ }^{81}$ "That Hollywood film exerts a profound ideological, moral, and psychological influence on its audiences is in fact recognized by the leaders of the industry." 82 Whatever the continuing influence of Hollywood, new media is revising its dominance.

New and changing technologies . . increasingly limit one of the most important aspects of state power: the effectiveness of intervention by governments to protect an internal cartel from the destabilizing cacophony of

\footnotetext{
75 See generally, e.g., Marshall Mcluhan \& Quentron Fiore, The Medium is the Massage (1967).

$76 I d$. at 22.

77 Id. at 26.

78 See id.

79 See Nancy Snow, supra note 72, at 219.

80 Though of course, whether Hollywood represents actual U.S. culture is quite another question. See generally Steve Macek, Urban Nightmares: The Media, the Right, and the Moral Panic over the Crty 203 (2006); Snow, supra note 72, at 198.

Foreign views of the social climate in America tended not to touch upon class at all but rather focused on race relations, along with observations on the American family and home life. America was viewed ambivalently as a culture operating at a swifter tempo than most of the world, with an orientation toward the kind of force and violence exhibited by Hollywood movies.
}

Id. at 200.

81 Monroe E. Price, The Market for Loyalties: Electronic Media and the Global Competition for Allegiances, 104 YALE L.J. 667, 675 (1994).

82 MACEK, supra note 80, at 203 ("Thus, former head of Columbia Studios David Puttnam once candidly admitted that ' $[w]$ hether we like it or not filmmakers are in the propaganda business . . . film sets the social agenda - more so, in my view, than television." ). 


\section{REVOLUTIONS AND EXPATRIATES}

the world. Even internally, government media policies that explicitly shape narratives seem to be throwbacks to another era, one in which competition for national identity could be contained. Even more in jeopardy is the "bubble," the power of law to contain debate within traditional physical boundaries. The consequences for law are intriguing because the passion for using law to regulate loyalties, fence out competition, and fabricate or reinforce national identities will not disappear. The market for loyalties persists; what changes are the market's players, the mechanisms for control, and, finally, the future of the state. ${ }^{83}$

Through international trade agreements such as the TRIPS Agreement, ${ }^{84}$ barriers to entry for cultural goods have been reduced. The practical structure of the Internet has made it more difficult for governments to regulate the access to social media and Internet content by their citizens. And the ubiquitous presences of "pirate sites" trading and selling unauthorized copies of music, films, television shows, sporting events, books and other publications has democratized access to virtually all popular creative content in production. ${ }^{85}$

The dissemination of culture has gone viral. It can no longer be mediated by the state, and can barely be mediated through the media producers themselves. Instead, viral culture is mediated, if at all, by the social media elite-the self-identified, highly active individuals who invest their time and resources to influence the trends on the Internet.

It is not enough to recognize that the world is interconnected, or that we all live within six degrees of separation from every other individual. ${ }^{86}$ The key to dissemination is the connectors-individuals who interact with decision makers, and in turn, engage much larger communities. ${ }^{87}$ These connectors may be intentional market-influencers or they may be unaware of the large intersecting communities in which they travel. So long as the information can be transferred through their networks, there node in the network retains significance. ${ }^{88}$

As influencers seek to stand at the nexus of significant communities, celebrities, political leaders and others with large, diffuse networks can play a role in accelerating infor-

${ }^{83}$ Price, supra note 81 , at 697.

${ }^{84}$ See generally, Agreement on Trade-Related Aspects of Intellectual Property Rights, Apr. 15, 1994, Marrakesh Agreement Establishing the World Trade Organization, Annex 1C, 33 I.L.M. 1197.

85 See Christopher Stewart \& Sam Schechner, Upload King's Quiet Steps, WALl.Sr.J., Jan. 30, 2012, at B1 (comparing the criminal indictments against Megaupload, Ltd. with the equally large RapidShare AG, a Switzerland-based cyberlocker which supports "tens of millions of visitors each month.").

${ }^{86}$ John Markoff \& Somini Sengupta, Separating You and Me? 4.74 Degrees, N.Y. TIMEs, Nov. 22, 201 1, at B1.

${ }^{87}$ See Malcolm Gladiwell,. The Tipping Point 30 (2000); Peter Morville, Social Network Analysis, SEMANTIC STUdIOS (Feb. 21, 2002), http://semanticstudios.com/publications/semantics/000006.php.

${ }^{88}$ Compare this to the diffusion model of decision making. An "S-shaped adoption curve persists in a wide variety of settings as early adopters represent a slow sample; the exponential growth of the broad public; and the trailing off of the adoption curve as the laggards take up the process. Information flow parallels this model. When a sufficient number of nodes communicate to their networks, the information expand exponentially. The value of the nodes affects the rate of rate of adoption rather than the shape of the curve." See generally, Gerald Silverberg, Giovanni Dosi \& Luigi Rosenigo, Innovation, Diversity and Diffusion: A Self-Organisation Model, 98 ECoN. J. 1032, 1032-1052 (1988); Zhang Xi, Yang Xuecheng, \& Zhang Xiaohang, Key Influencers in Virtual Community, Marketing Science Innovations and Economic Development - Proceedings of 2009 Summit International Marketing Science and Management Technology Conference 270, 274 (Dec. 2009), available at http://www.bmtfi.com/en/search/download-file.php?id=4462. 
mation flow on the system-either to expand the information wave or to counter the wave and calm the ripples. For governments interested in content control, such calming and control are central to the next generation of societal control.

\section{THE TOTALITARIAN RESPONSE TO THE RISE OF THE NETWORKED COMMUNITY}

No one can deny that a network (a world network) of economic and psychic affiliations is being woven at ever increasing speed which envelops and constantly penetrates more deeply within each of us. With every day that passes it becomes a little more impossible for us to act or think otherwise than collectively. 89

Governments recognize the need to exploit normative persuasion on their neighbors to encourage an understanding amongst people and to suggest that their political views should be held in common regard among all peoples of the globe. To the extent this normative persuasion is a competition of ideas and values, it is the very marketplace of ideas that has been enshrined in U.S. jurisprudence and central to U.S. value system. To the extent such clash of ideologies may be deemed threatening, governments may seek to restrict the discourse. Particularly for totalitarian regimes already struggling against the tide of disintermediation and erosion of state control, the rise of social media may seem the last straw.

Predictably, some of the world's most repressive regimes, like those in China and Iran, have created a pervasive, sophisticated, and multilayered system of censorship that significantly limits the content that citizens can access or post on the internet and transmit via mobile phones, particularly when it comes to topics deemed sensitive by the authorities. Harsh laws, an apparatus of monitoring and surveillance, torture, and imprisonment await those who cross the-red lines $\square$ separating acceptable from unacceptable thought. ${ }^{90}$

In addition to the heightened arrest of dissidents, ${ }^{91}$ China has undertaken a number of steps to thwart access to Internet research and social media. In addition to blocking specific terms, such as "Jasmine Revolution,"92 it launched attacks against Google ${ }^{93}$ and used invisible proxy servers to monitor Internet traffic and disrupt particular content. ${ }^{94}$ "The Chinese government is thought to have tightened communications in response to political unrest in the Middle East. Google discovered that problems with Gmail from within China came in

\footnotetext{
89 Pierre Teilhard De Chardin, The Formation of the Noosphere, in THE Future of MAN (1964).

90 Karin Deutsch Karlekar \& Sarah G. Coo, Access and Control: A growing diversity of threats to internet

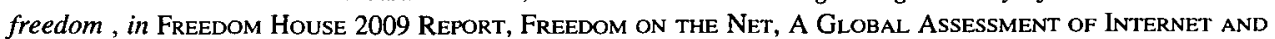
Digrtal Media 1 (Apr. 1, 2009).

91 Michael Wines, Crackdown Continues on Activists in China, N.Y. Tomes, Jan. 18, 2012, at A8.

92 See Johnson, supra note 18.

93 See Tom Krazit, Google to Stop Censoring in China, May Pull Out, CNET (Jan. 12, 2010) http:// news.cnet.com/8301-30684_3-10433538-265.html.

94 See Robert Lemos, How China and Others are Altering Web Traffic, Technologyreview.com (Mar. 24, 2011), http://www.technologyreview.com/web/37074 (subtitled: "Invisible' servers let governments quietly intercept and modify their citizens' online communications.").
} 
the form of an attack that caused the Web application to freeze when a user took certain actions, such as clicking the "send" button."95 China has explored a number of efforts to promote harmony and communitarianism values by controlling the content available to its citizens and the social media created by them.

While China has been the most visible of media managers, it has certainly not been alone. "Other nations have used man-in-the-middle tactics to interfere with Web traffic. Tunisia took a similar approach to grabbing Facebook logins in order to perform surveillance on its citizens after widespread protests of the reign of Zine El Abidine Ben Ali. The protests followed massive unrest in other countries such as Yemen and Tunisia's next door neighbor, Libya." 96 When protests reached Libya, it ordered the state-controlled telecommunications companies to disable all Internet traffic in the country. ${ }^{97}$

The interference with intermittent access, however, pales in comparison to the more concerted efforts led by Russia to stop what it labels ideological warfare. Harkening back to the scarier era of the Cold War, at the turn of the millennium there came "Russian calls at the United Nations for a world-wide information security policy and to limit the development of information weaponry and operations." 98 Russian policy has been to use disinformation against its own rebels while accusing its competitors of launching acts of ideological aggression against its sovereignty. 99 "At a U.N. disarmament conference in 2008, Sergei Korotkov of the Russian Defense Ministry argued that anytime a government promotes ideas on the Internet with the goal of subverting another country's government-even in the name of democratic reform-it should qualify as 'aggression.' And that, in turn, would make it illegal under the U.N. Charter."100

Since social media is inherently decentralized, careful planning by a belligerent state has the potential to be successful in affecting the outcome of armed conflicts. Had the Tunisian government used social media to spread disinformation and confusion rather than merely trying to turn the communications off, there might have been different results. In Jordan, progovernment demonstrations have dwarfed those of the opposition. ${ }^{101}$ Whether this is representative democracy or effective use of media resources cannot be easily assessed.

The consequence of these changes and the use of social media as a state weapon of disinformation leads to the conclusion that social media is simply another tool in a complex competition for resources, authority, and sovereignty.

\section{CONCLUSION}

The intersection of state disintermediation and social media has become an increasingly destabilizing mix. Today, a greater percentage of the world's population has greater

\footnotetext{
95 Id.

96 Id.

97 Libya Internet Shut Down Amid Protests, Later Restored, HuFFInGton Post (Feb. 18, 2011), http:// www.huffingtonpost.com/201 1/02/18/libya-internet-shut-down-_n_825473.html.

98 Thomas, supra note 54.

99 See Tom Gjelten, Seeing The Internet As An 'Information Weapon,' Nat'L Public Radio (Sept. 23, 2010), http://www.npr.org/templates/story/story.php?storyId=130052701.

100 Id.

101 Amy Hybels, Activists demand change in peaceful Jordan protest, CNN (Feb. 26, 2011), http:// articles.cnn.com/201 1-02-25/world/jordan.protests_1_anti-government-protesters-police-and-protesters-progovernment.
} 
access to more information than ever before; states have less control over the information available to their subjects; and expatriate communities and individuals living in the Diaspora have greater access to their homeland and to each other than ever before.

Some expatriate communities will use this greater access to destabilize the current government in an effort to affect political change. But whether this involvement is through accepted forms of civic engagement or through illegal goals of financing and arming conflict will depend on the particular situation without regard to the existence of the greater communications access.

To this mix, state disintermediation and the transition from state-controlled monopolies over finance, trade and telecommunications to supranational organizations, local governments and multinational corporations will stress the status quo in every country. Totalitarian regimes see the transformation in the role of the twenty-first century as an existential threat to the dominance they have held throughout the twentieth century.

The net result of these changes will make for a volatile situation, particularly where the risk of open defiance will lead to governmental retaliation. Those states which recognize the need to manage this volatility will increase the engagement with their constituents. But where the state is unwilling to allow such discourse, the speed of communication and role of outside influences will make these conflicts ignite faster and more dangerously than ever before. 